\title{
A study of students' attitudes towards using ICT in a social constructivist environment
}

Silin Yang

Institute for Adult Learning, Singapore

\author{
David Kwok \\ Republic Polytechnic, Singapore
}

\begin{abstract}
This study aims to examine the factors that support or hinder students' attitudes towards using information and communication technology (ICT) in problem-based learning (PBL) using the technology acceptance model (TAM) (Davis, 1989) among polytechnic students. A total of 737 first-year polytechnic students in Singapore participated in the cross-sectional survey study by completing a questionnaire (The assessment of attitude and intention to use ICT tools among polytechnic students), which gathered both quantitative and qualitative data. Based on the analysis of the quantitative data, perceived usefulness and perceived ease of use are found to be significantly and positively correlated with attitudes towards using ICT. Results from the analysis of the qualitative data suggest five major themes (engagement, communication, information gathering, collaboration and efficiency) on what students enjoyed most about using ICT. On the other hand, Internet connectivity, usability, technical issues and ICT competency are the four other themes that categorised the difficulties students faced using ICT. An important implication is to develop polytechnic lecturers' competency in the use of ICT-enabled learning tools as a priority to enable them to successfully integrate ICT in their PBL lessons.
\end{abstract}

\section{Introduction}

In the 21st century, there has been a concerted push for information and communication technology (ICT) integration in education. ICT is an "all-encompassing term that includes the full gamut of electronic tools by means of which we gather, record and store information, and by means of which we exchange and distribute information to others" (Anderson, 2010, p. 4). It includes laptop computers, electronic pads, smartphones, along with the broadband Internet, interactive Web 2.0 technologies and cloud applications. Through the widespread use of ICT in education, learning can take place at anytime and anywhere.

Facilitating teaching and learning through the use of ICT constitutes a major part of educational programs (Thomas \& Stratton, 2006), and in many developed countries, many higher educational institutes are equipped with the infrastructure to conduct ICT-mediated teaching and learning (Abedalaziz, Jamaluddin, \& Leng, 2013). In Singapore, three ICT master plans for schools including higher education institutes (1999-2014) were developed and implemented by the Ministry of Education aimed at enriching and transforming the learning environment of students and equip them with the critical competencies and dispositions to succeed in a knowledge economy (Chung, 2011).

In many educational institutes, technology has been seen as one of the key drivers for the improvement of teaching and learning. The use of ICT is helpful in facilitating teaching and learning for both teachers and students in the classroom. Achieving meaningful use of ICT in the field of education can be influenced by many factors, which include technology availability, accessibility of ICT equipment and technical and administrative support (Al-Ruz \& Khasawneh, 2011; Fu, 2013; Lin, Wang, \& Lin, 2012; Srivastava et al., 2014). Among these factors, users' attitudes towards the use of technology could impact teaching and learning in the classroom (Abedalaziz et al., 2013; Pelgrum, 2001).

A number of studies have shown that appropriate use of ICT can raise the educational quality in higher educational institutes (Sánchez \& Alemán, 2011; Sosin, Blecha, Agarwal, Bartlett, \& Daniel, 2004). In the study by Sosin et al. (2004), it was found there were some positive impacts on student performance due to ICT usage.

Sánchez and Alemán (2011) also suggested that ICT can assist in transforming a teaching environment into a learner-centred one in a higher educational institute setting, and to achieve successful integration of ICT in class, it requires efforts from teachers, students and school administrators. The successful use of ICT in teaching and learning will depend largely on the attitudes of the teachers and students towards the use of ICT. 
Although most studies have focused on investigating teachers' intentions towards the use of ICT (Doering, Hughes, \& Huffman, 2003; Hu, Clark, \& Ma, 2003; Ma, Andersson, \& Streith, 2005; Sang, Valcke, Braak, \& Tondeur, 2010; Serhan, 2009; Teo \& Van Schaik, 2009), few studies have examined the factors that influence polytechnic students' intentions to use ICT (Attuquayefio \& Addo, 2014; Choy, Wong, \& Tan, 2011; Van De Bogart \& Wichadee, 2015). Motivated by this need, the objective of the study was to examine polytechnic students’ attitudes towards using ICT in a problem-based learning (PBL) environment.

\section{Review of related literature}

\section{The adoption of ICT in PBL}

PBL is a learner-centred pedagogy characterised by learners working collaboratively in teams to solve problems pertaining to learners' domain of study in a social constructivist environment (Hmelo-Silver, 2004; Lew \& Schmidt, 2012; Norman \& Schmidt, 1992; Schmidt \& Moust, 2000). Several studies have been conducted to examine the impact of ICT on students' learning in a PBL environment (e.g. Kerckaert, Vanderlinde, \& van Braak, 2015; Lim, 2005; Strømsø, Grøttum, \& Hofgaard Lycke, 2004). In a pilot study on the use of two online forums to support inquiry in the PBL curriculum for a law subject in a Singapore tertiary vocational institute, Lim (2005) found that there were higher levels of participation from the students in online chat rooms compared to online discussions on content topics. This could be due to a lack of knowledge and experience, which affects confidence in using online forums for discussions (Lim, 2005, p. 921).

Results of other studies have also shown that the use of ICT supports collaborative learning, knowledge construction and critical thinking, participation and diversifying of ideas, scaffolding of concepts and selfreflection among students in a PBL environment (Hack, 2013; Ioannou, Brown, \& Artino, 2015; Tambouris et al., 2012). In the study by Tambouris et al., the use of ICT resulted in learners becoming more active, collaborative and productive. In addition, Hack (2013) has also stated that the use of Web 2.0 technologies can provide the tutor or facilitator with an opportunity to scaffold and assess the PBL process. In a study on using ICT in a PBL approach, Reyes and Gabb (2005) found that ICT supported deep learning in that it provided a convenient means to interact and communicate ideas, which is a central component of the PBL approach. Despite the numerous studies on the pervasive use of ICT tools in PBL (e.g. Hack, 2013; Hsu, Hwang, Chuang, \& Chang, 2012; Ioannou et al., 2015), few studies have evaluated polytechnic students' intention to use these tools in a social constructivist environment.

\section{Technology acceptance model}

In studying user acceptance and use of information technology and information system, the technology acceptance model (TAM) is one of the most cited models. Developed by Davis, Bagozzi, and Warshaw (1989), TAM aims to explain how users perceive and use technology by specifying the relationships between perceived usefulness, perceived ease of use and attitude towards computer use. The TAM constructs are defined as follows: perceived usefulness as the degree to which a user believes that using technology will increase his/her job performance; perceived ease of use is the degree to which a user believes that using technology is free of effort; and attitude towards computer use refers to the level of liking a user derives from using the computer (Davis et al., 1989, p. 320).

From TAM (see Figure 1), perceived usefulness and perceived ease of use are posited to have direct influences on attitudes towards computer use (Davis et al., 1989; Venkatesh \& Davis, 1996). In addition, perceived ease of use has a direct influence on perceived usefulness (Edmunds, Thorpe, \& Conole, 2012; Teo \& Van Schaik, 2009; Wong, Osman, Choo, \& Rahmat, 2013). TAM has been validated in many studies by examining users’ attitudes towards various technology adoptions such as online forums (Camarero, Rodríguez, \& San José, 2012), e-portfolio systems (Shroff, Deneen, \& Ng, 2011), interactive whiteboards (Shen \& Chuang, 2010) and podcasting (Zacharis, 2012). 


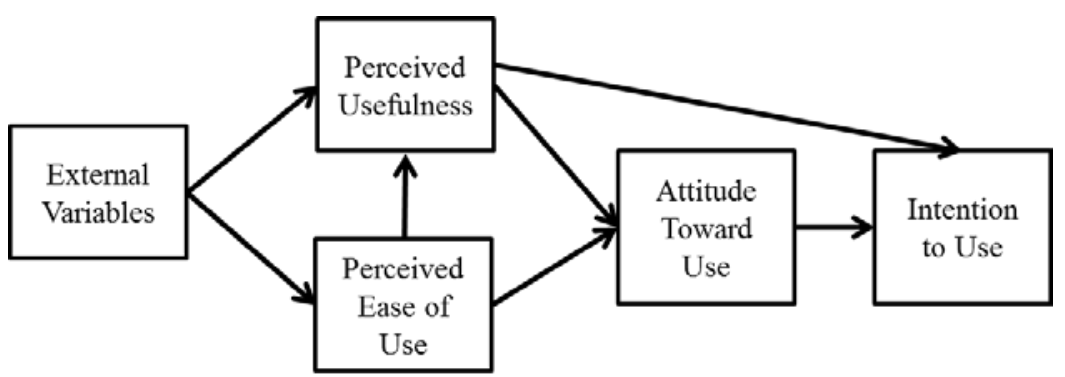

Figure 1. TAM (adapted fromVenkatesh, 2000, p. 345)

\section{Studies on ICT adoption}

Although there is plethora of quantitative studies using various behavioural models to investigate user acceptance of ICT, studies analysing both quantitative and qualitative data in tandem are limited. Smarkola (2011) posited that analysing both quantitative and qualitative data in tandem adds depth to the research and allows the researcher to identify weaknesses in the quantitative data and bridge the gap between quantitative and qualitative data, which leads to more purposeful conclusions.

Siragusa and Dixon (2008) examined the attitudes of a group of undergraduate students towards their use of and engagement with ICT interactions. Although the collected quantitative data revealed that students believed interacting with ICT was pleasant, helpful and easy, the qualitative findings showed that some students experienced feelings of anxiety and intimidation when working with ICT.

In another study on technology acceptance, Wu (2012) investigated factors that influenced the adoption of an emergency alert system in a university. By triangulating the focus groups findings with the survey data analysis, he found that analysing both quantitative and qualitative data facilitated a deep understanding of perceived usefulness and perceived ease of use, both factors influencing technology user acceptance and behaviour.

Based on the existing literature found, there have been limited and scant studies using both quantitative and qualitative data in tandem to assess polytechnic students' attitude to use ICT in a PBL environment, and this study attempts to address the gap in the literature.

The research questions of this study are as follows:

(1) What are the relationships among perceived ease of use, perceived usefulness and attitudes towards the use of ICT among polytechnic students in a social constructivist environment?

(2) What are the students' positive and negative reactions towards the use of ICT for PBL learning?

\section{Method}

Addressing the complexity of the various factors that impact students' intention to use ICT necessitates analysis of both quantitative and qualitative data to gain a more in-depth and comprehensive understanding of the data collected. In this study, data were drawn from both the quantitative and qualitative components of the questionnaire.

\section{Participants}

A total of 737 first-year students at a polytechnic in Singapore taking a compulsory foundational module, "Cognitive Processes and Problem Solving”, participated in this study. Among the participants, 446 (60.5\%) were females and $291(39.5 \%)$ males. Their mean age was 17.36 years $(S D=1.50)$. All the students owned and used laptops during the lessons in school, and they have access to various ICTs (e.g., Google Apps, Edmodo, Popplet) to support their learning during the PBL lessons.

\section{Educational context}

This study was conducted in a polytechnic in Singapore which delivers more than 230 modules each semester from a wide range of diplomas in various fields. Learning typically takes place using a PBL approach, where a problem scenario is presented to a class of 25 students who work in small teams of five alongside their assigned 
class facilitator, once a week over a period of 13 weeks. Each PBL day is typified by a schedule of three meetings with facilitator interaction, and interspersed by two periods of self-study (O'Grady, Yew, Goh, \& Schmidt, 2012). The module chosen for this study is a compulsory first-year general module, "Cognitive Processes and Problem Solving”. During the lessons, students were introduced to the various types of ICT to support their collaborative learning in teams. For instance, students used Google Apps to analyse the problem in teams, Popplet to perform a mind map to generate ideas and Edmodo to participate in the online discussion.

\section{Instrument}

The items in the questionnaire employed in this study comprised validated items adapted from several empirical studies using TAM (Compeau \& Higgins, 1995; Davis, 1989; Thompson, Higgins, \& Howell, 1991) by replacing "computers" with "ICT" in the questionnaire. Instructions in the questionnaire informed the students that the purpose of the questionnaire was to find out about their attitudes towards and intention to use ICT tools in a social constructivist environment, with specific focus on the module on Cognitive Processes and Problem Solving. Before the conduct of the study, the questionnaire was validated by a panel of three lecturers for face and content validities. All three lecturers possess educational research experience and have several publications. Out of the three lecturers, two had expertise in the area of ICT.

The final questionnaire comprises 12 statements on perceived ease of use (4 items), perceived usefulness (4 items) and attitudes towards the use of ICT (4 items). Participants were asked to give their responses to each of the statement on a 5-point Likert scale, ranging from 1 (strongly disagree) to 5 (strongly agree). Two openended questions on what students enjoyed most and the difficulties they faced using ICT were included in the questionnaire.

\section{Procedure}

Participants from the various classes completed the online questionnaire with the assistance of the lecturers who administered the questionnaire in class towards the end of the semester. All participants were briefed on the purpose of the study, and were informed that their participation was strictly voluntary and their anonymity safeguarded. The participants had the right to not participate or withdraw from the study at any time. Participants were also informed that no module credit would be given for participating in the study and their responses would not affect their assessment grades. On average, the respondents took no more than 20 minutes to complete the questionnaire. The study was approved by the Ethics Review Committee at the institute where the study was conducted.

\section{Data analysis}

The analysis of the data was carried out in two stages. The first stage involved analysing the quantitative data by performing several statistical tests (i.e., mean, standard deviation, Cronbach's alpha and Pearson correlation coefficient). The second stage involved analysing the qualitative information from the open-ended questions in the questionnaire with the help of SPSS Text Analytics for Surveys 4.0.1 software. This tool provided a semantic analysis of the responses including classification and keyword frequencies. Comments such as "Nil", “NA”, “No comment”, “-”, “none”, “...” and blank entries were first filtered out. The remaining qualitative comments were coded, conceptualised and categorised. The researchers used both a priori (i.e., a "start list" of pre-set codes derived from past research findings) and emergent coding (i.e., concepts that are different from the pre-set codes) to aggregate common themes and the clustering of related themes to be compared and contrasted in order to gain an insight into attitudes towards the use of ICT. The results from both analyses were studied and synthesised.

\section{Results}

\section{Quantitative data}

The descriptive statistics of the measurement items are shown in Table 1. All 737 participants answered the questions in the questionnaire. All means are above the midpoint of 3.0, ranging from 3.47 to 3.80. This indicates an overall positive response to the constructs that are measured in this study. The small standard deviation values ranged from .81 to .90 , indicating a narrow spread of item scores around the mean. The skewness (from -.60 to -.17) and kurtosis (from .06 to .68) were all within the suggested cut-offs of absolute values less than 3 and 10 respectively (Kline, (2005), indicating univariate normality. 
Overall, the attitude towards use of ICT (AT) dimension has lower mean scores for all the items as compared to the perceived ease of use (PE) and perceived usefulness (PU) dimensions. This could be attributed to the influence of both PE and PU on AT, and will be discussed in the later sections. A closer examination revealed that the questionnaire item with the highest rating was "I find ICT easy to use" $(n=737$, Mean $=3.80, S D=$ $.85)$, and the item with the lowest item was "I look forward to lessons that require me to use ICT" ( $n=737$, Mean $=3.47, S D=.87)$.

Table 1

Descriptive statistics of questionnaire items

\begin{tabular}{|c|c|c|c|c|c|}
\hline Construct & Item & Mean & $S D$ & Skewness & Kurtosis \\
\hline \multicolumn{6}{|c|}{ Perceived ease of use (PE) } \\
\hline PE1 & I find ICT easy to use. & 3.80 & .85 & -.461 & .291 \\
\hline PE2 & $\begin{array}{l}\text { My interaction with ICT is clear and } \\
\text { understandable. }\end{array}$ & 3.79 & .84 & -.400 & .138 \\
\hline PE3 & $\begin{array}{l}\text { I find it easy to get ICT to do what I want } \\
\text { them to do. }\end{array}$ & 3.74 & .85 & -.362 & .060 \\
\hline PE4 & $\begin{array}{l}\text { Interacting with ICT does not require a lot of } \\
\text { mental effort. }\end{array}$ & 3.54 & .90 & -.360 & .229 \\
\hline \multicolumn{6}{|c|}{ Perceived usefulness (PU) } \\
\hline PU1 & Using ICT improve my learning. & 3.72 & .84 & -.500 & .450 \\
\hline PU2 & Using ICT will enhance my effectiveness. & 3.77 & .84 & -.600 & .682 \\
\hline PU3 & Using ICT will enhance my productivity. & 3.73 & .85 & -.535 & .570 \\
\hline PU4 & I find ICT a useful tool in my learning. & 3.77 & .84 & -.545 & .644 \\
\hline \multicolumn{6}{|c|}{ Attitude towards use of ICT (AT) } \\
\hline AT1 & ICT make learning more interesting. & 3.61 & .81 & -.227 & .204 \\
\hline AT2 & $\begin{array}{l}\text { I look forward to lessons that require me to } \\
\text { use ICT. }\end{array}$ & 3.47 & .87 & -.243 & .260 \\
\hline AT3 & Working with ICT is fun. & 3.52 & .86 & -.173 & .188 \\
\hline AT4 & I like the idea of using ICT. & 3.55 & .85 & -.297 & .287 \\
\hline
\end{tabular}

The coefficient of reliability of each construct was assessed using Cronbach's alpha. DeVellis (2003) recommended that a Cronbach's alpha value of .70 is considered acceptable. As shown in Table 2, the reliabilities of all the constructs ranged from .90 to .93, well above the recommended value. Hence, this shows that all the constructs exhibited high internal consistencies.

As shown in Table 2, there was a significant and positive correlation between perceived ease of use and perceived usefulness $(r=.73, p<.01)$. There was also a significant and positive correlation between perceived ease of use and attitude towards use of ICTs ( $r=0.65, p<.01)$, and between perceived usefulness and attitude towards use of ICT $(r=.74, p<.01)$, which was also shown in other studies (Alharbi \& Drew, 2014; Alsamydai, 2014; Koch, Toker, \& Brulez, 2011). The strengths of these correlations are considered large based on Cohen's (1988) suggestion of $r>.50$.

Table 2

Mean, standard deviation, Cronbach's alpha and bivariate correlations among the constructs

\begin{tabular}{lcccccc}
\multicolumn{1}{c}{ Construct } & Mean & SD & Cronbach's alpha & \multicolumn{3}{c}{ Correlation } \\
\cline { 4 - 7 } & & & & PE & PU & AT \\
\hline Perceived ease of use (PE) & 3.72 & .75 & .90 & 1 & $.73^{*}$ & $.65^{*}$ \\
Perceived usefulness (PU) & 3.75 & .76 & .93 & $.73^{*}$ & 1 & $.74^{*}$ \\
Attitude towards use of ICT (AT) & 3.54 & .76 & .92 & $.65^{*}$ & $.74^{*}$ & 1 \\
\hline
\end{tabular}

$* p<.01$

\section{Qualitative data analysis}

The two open-ended questions in the questionnaire provided qualitative information on students' intentions to use ICT in a social constructivist environment. About $18 \%$ of the participants provided comments such as "Nil", "NA”, “No comment”, “-”, “none”, “...” or did not respond. These were filtered out. The remaining qualitative comments were coded, conceptualised and categorised. Prior to the main themes being extracted from the responses given, a frequency of the top 10 for each positive and negative words was tabulated from the two open-ended questions on "what students enjoy most about using ICT" and "what are the difficulties faced by 
students using ICT” (see Table 3 and Table 4) using the SPSS Text Analytics for Surveys 4.0.1 software. The top positive and negative words were “easier” $(n=65)$ and "slow” $(n=70)$ respectively.

Table 3

Frequency of positive words

\begin{tabular}{|c|c|c|}
\hline Positives & Bar & Frequency \\
\hline Easier & & 65 \\
\hline Convenient & & 61 \\
\hline Easy to use & & 57 \\
\hline Fast & & 55 \\
\hline Enjoyable & & 48 \\
\hline Efficient & & 40 \\
\hline Effective & & 30 \\
\hline Helpful & & 30 \\
\hline Entertaining & & 22 \\
\hline Interesting & & 17 \\
\hline
\end{tabular}

Table 4

Frequency of negative words

\begin{tabular}{llc}
\hline Negatives & Bar & Frequency \\
\hline Slow & & 70 \\
Bad & & 28 \\
Not user-friendly & & 21 \\
Not working & & 18 \\
Confusing & & 17 \\
Unable to use & & 16 \\
Disconnected & & 11 \\
Frustrated & & 11 \\
Troublesome & & 11 \\
\hline
\end{tabular}

\section{What students enjoyed most about using ICT}

Analysis of responses to the questions regarding what the students enjoyed most about using ICT indicated five major emergent themes: communication, collaboration, information gathering, efficiency and engagement (see Figure 1). It is noteworthy that engagement had the highest number of respondents and the highest number of shared responses with efficiency. This is followed by efficiency and information gathering, with the second highest shared responses.

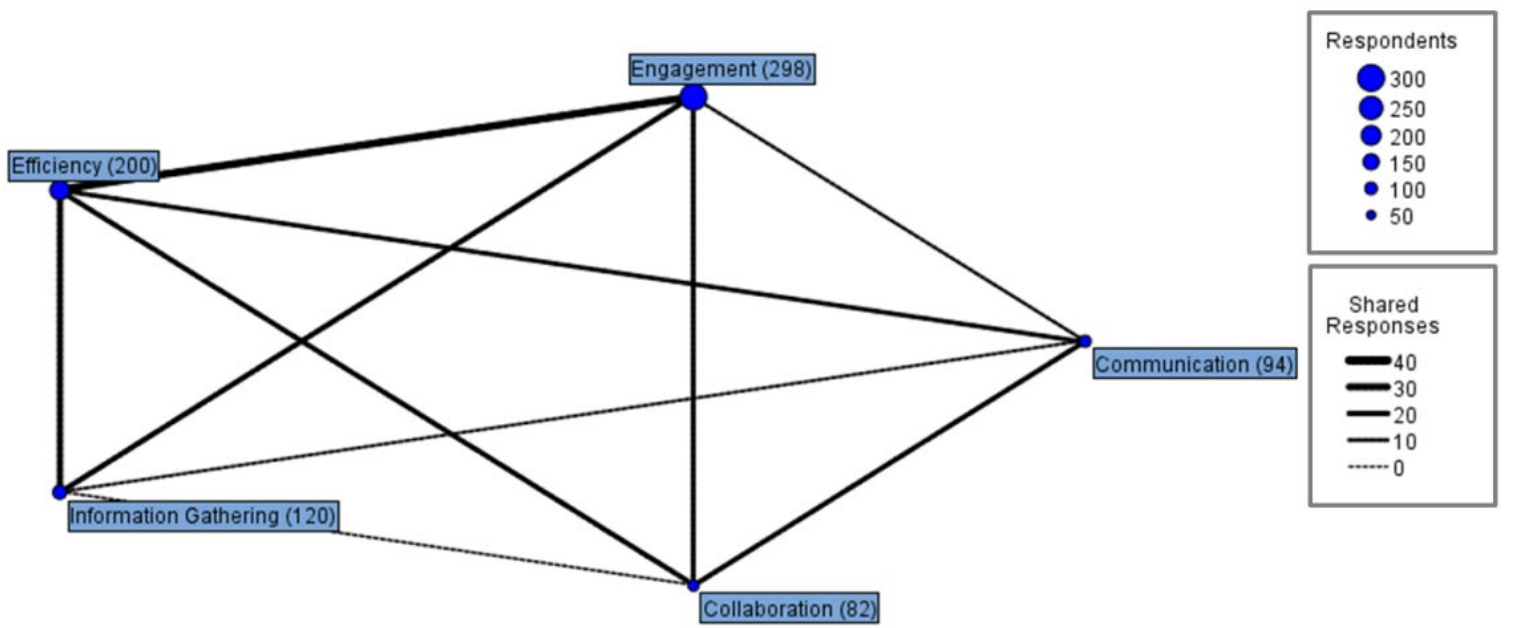

Figure 1. Relationships among themes on what students enjoy most about using ICT

Students responded that they enjoyed the experience of using ICT as it keeps them engaged. The wide array of learning materials that are available on the Internet also resulted in the increase of efficiency in information gathering as they no longer need to rely solely on printed books and other materials which are housed in the library with limited copies. One of the students indicated: 
I am able to find information easily using Google and I do not have to waste time looking through books physically to find the resources I need.

The use of ICT also enables students to communicate, share and work collaboratively anywhere and anytime (Koç, 2005). A number of students indicated in the questionnaire that ICT has a significant role to play in supporting and enhancing their communication with their peers. They see the use of ICT as a means of communication to share ideas and information to collaboratively construct knowledge. They have the opportunity to analyse problems and explore ideas as well as develop concepts. Not only are they able to acquire knowledge together, but they are also able to share diverse learning experiences with one another in order to express themselves and reflect on their learning. One student commented:

There is easier communication and sharing of ideas among team members. Workload is also shared among the team members, and hence we are able to complete the given assignment before due time.

Table 5 provides a description and frequency of the five themes identified, with more examples of students' comments.

Table 5

Themes, concepts and sample responses on what students enjoy most about using ICT

\begin{tabular}{llll}
\hline Themes & $\begin{array}{l}\text { Examples of } \\
\text { concepts }\end{array}$ & Frequency &
\end{tabular}

\section{Difficulties faced using ICT}

Although students indicated that they enjoy the use of ICT during the lessons, there are many factors which will impede the successful implementation of ICT in the classroom. To have a balanced perspective, besides identifying the positive comments of students on what they enjoyed most using ICT, open-ended comments were also coded and categorised to analyse the difficulties they faced using ICT.

The result indicated four themes based on the categorisation of the difficulties faced by students using ICT: Internet connectivity, usability, technical issues and ICT competency (see Figure 2). It is interesting to note that usability had the highest responses whereas Internet connectivity and technical issues had the highest shared responses. This is followed by Internet connectivity and usability with the second highest shared responses. 

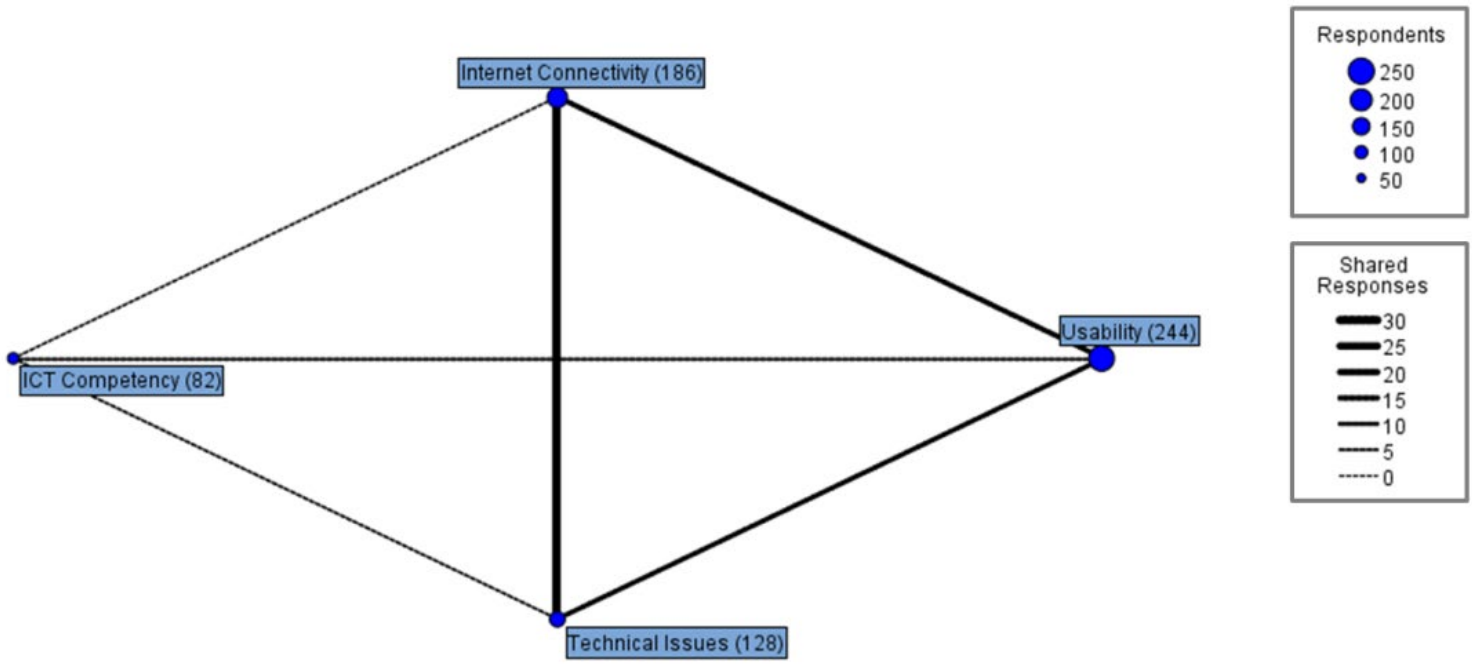

Figure 2. Relationships among themes on difficulties students faced using ICT

Some students indicated that the functions of some of the ICT were too complicated to understand and comprehend. One student indicated:

Sometimes, the ICT is quite complicated and takes a while for us to familiarise with it. Not everyone can communicate or relate well to ICT which could also affect the productivity in our team.

Other students' responses indicated technical support provided by these ICT is poor. These technical difficulties actually hinder the process of their learning. A group of students who described themselves as computer illiterate commented that they are not motivated to use ICT in their learning as they are not equipped with the necessary skills.

Table 6 provides a description and frequency of the four themes that were identified, with additional examples of students' responses.

Table 6

Themes, concepts and sample responses on the difficulties students faced using ICT

\begin{tabular}{llll}
\hline Themes & $\begin{array}{l}\text { Examples of } \\
\text { concepts }\end{array}$ & Frequency &
\end{tabular}




\section{Discussion and implications}

The study is guided by two research questions: (1) What are the relationships among polytechnic students' perceived level of ease of use, usefulness and attitude towards the use of ICT? (2) What are the students' positive and negative reactions towards the use of ICT for PBL learning? Overall, the findings from the quantitative analyses corroborated with the qualitative analyses. Consistent with prior research (Davis, Bagozzi, \& Warshaw, 1989; Hu et al., 2003), the findings of this study indicate that perceived usefulness and perceived ease of use are two constructs which are significant determinants of attitude towards ICT usage.

From the quantitative analysis, perceived usefulness was significantly correlated with attitude towards the use of ICT. A plausible explanation is that when students perceived ICT as being useful in their learning, they would be highly engaged in the use of ICT. Based on the qualitative analysis, four of the themes (information gathering, communication, collaboration and efficiency) identified were important features of ICT which the students found useful. This corresponded to findings by some of the studies conducted which stated the ICT provides ready and efficient source of information (Srivastava et al., 2014) and promotes engagement and communication with others (Barak \& Ziv, 2013).

Similarly, from the quantitative analysis, perceived ease of use was also significantly correlated with attitude towards the use of ICT. When ICT is perceived as being difficult to use, students tend to develop an unfavourable attitude towards ICT usage. In the qualitative analysis, usability was one of the themes on difficulties faced by students using ICT that was found to have the highest responses. This finding corroborated with students perceiving ICT as one that is complicated and not willing to use in the classroom (Pelgrum, 2001).

In agreement with what TAM postulated, the results also show that perceived ease of use had a significant influence on perceived usefulness. This suggests that if ICT is perceived as easy to use and nearly free of mental effort, it would be viewed as more useful (Shroff, Deneen, \& Ng, 2011). On the other hand, ICT is perceived to be useless if students believe they do not know how to use it. From the qualitative analysis, students' competency in using ICT is one contributing factor that determines if ICT is easy to use. This is also reflected in the study which found that usefulness and ease of use are key aspects of students' attitudes towards ICT in all areas of their lives (Edmunds, Thorpe, \& Conole, 2012).

From the qualitative analysis, out of the four identified themes on the difficulties students faced using ICT, usability had the highest number of responses. This corroborated with the quantitative analysis that among all items in the construct on perceived ease of use, PE4 (Interacting with ICT does not require a lot of mental effort) had the lowest mean rating. One possible reason is that if the usability of the ICT is low, students would require more efforts to learn how to use it (Fu, 2013).

Out of the five identified themes on what students enjoyed most about using ICT, engagement and efficiency had the highest number of responses compared to the other themes, and this finding is consistent with the quantitative analysis. Item PU2 (Using ICT will enhance my effectiveness) had the highest mean rating compared to the three other items associated with the construct on perceived usefulness. Similarly, item AT1 (ICT make learning more interesting) had the highest mean rating compared to the other items in the same construct on attitude towards using ICT. When students find the lesson interesting and they are engaged in learning, they tend to develop a positive attitude towards using ICT.

Although ICT plays a major role in transforming teaching and learning, inappropriate choice of ICT tools and the lack of considerations of the usage will influence students' motivation to use ICT in the classroom (Lim, 2005). When selecting ICT tools for usage, it is critical to ensure that there is effective and adequate technical support for the smooth implementation of ICT so that students will perceive ICT to be easy to use. To provide technical support for the smooth implementation of ICT, lecturers need to be firstly equipped with the necessary knowledge and competence to deal with the technical issues arising during the introduction of ICT in the classroom. This can be carried out by offering training workshops in the institute to equip the lecturers with the knowledge and skills to use ICT in the classroom. In this way, lecturers would develop confidence to resolve technical issues faced by students using ICT independently and skilfully. 


\section{Limitations and future research}

This study is not without limitations. The study employed a self-reported questionnaire which may be subject to social desirability bias, where respondents have the tendency to over-report or under-report their ratings to try to meet the expectations of the researchers (Fisher, 1993). Furthermore, the inferences from the open-ended comments in the questionnaire cannot be clearly established as we were not able to clarify and triangulate our interpretation with the students. Researchers were also unable to capture responses from students who did not provide any feedback in the open-ended questions. As our study results were obtained from a single study at one polytechnic in Singapore, caution must be taken when generalising the findings to the entire population of Singapore's polytechnic students or to polytechnic students in other countries with different educational and cultural environments. To increase the validity and the generalisability of the findings of this study, future research could include polytechnic students from different polytechnics or other higher educational institutes.-

\section{Conclusion}

This study has provided some interesting insights into the attitudes of polytechnic students towards their use of ICT in a PBL environment. Students' attitudes towards using ICT are generally favourable, and there are a multitude of factors that support or hinder their usage. Students' perceived ease of use and perceived usefulness were found to be significant determinants of attitudes towards the use of ICT. When students view ICT as useful and easy to use, their engagement with ICT is high. Given the social constructivist PBL environment where students are often engaged in collaborative learning and self-directed leaning, it is not surprising that the students perceived high engagement with the use of ICT. However, ICT competency, Internet connectivity, technical issues and usability are some factors that hinder students' usage of ICT.

For a successful integration of ICT in the PBL lessons, the training of lecturers on the use of ICT-enabled learning tools should be a priority in their professional development. Polytechnic administrators need to ensure that quality Internet infrastructure and technical support are provided to support students' learning with ICT.

\section{References}

Abedalaziz, N., Jamaluddin, S., \& Leng, C. H. (2013). Measuring attitudes toward computer and internet usage among postgraduate students in Malaysia. Turkish Online Journal of Educational Technology-TOJET, 12(2), 200-216. Retrieved from ERIC database. (EJ1015431)

Al-Ruz, J. A., \& Khasawneh, S. (2011). Jordanian pre-service teachers' and technology integration: A human resource development approach. Journal of Educational Technology \& Society, 14(4), 77-87. Retrieved from http://www.ifets.info/journals/14_4/8.pdf

Alharbi, S., \& Drew, S. (2014). Using the technology acceptance model in understanding academics' behavioural intention to use learning management systems. International Journal of Advanced Computer Science and Applications, 5(1), 143-155. https://doi.org/10.14569/IJACSA.2014.050120

Alsamydai, M. J. (2014). Adaption of the technology acceptance model (TAM) to the use of mobile banking services. International Review of Management and Business Research, 3(4), 2039-2051. Retrieved from http://www.irmbrjournal.com/papers/1421123221.pdf

Anderson, J. (2010). ICT transforming education: A regional guide. Bangkok: UNESCO.

Attuquayefio, S. N., \& Addo, H. (2014). Using the UTAUT model to analyze students' ICT adoption. International Journal of Education and Development using Information and Communication Technology, 10(3), 75-86. Retrieved from ERIC database. (EJ1059042)

Barak, M., \& Ziv, S. (2013). Wandering: A Web-based platform for the creation of location-based interactive learning objects. Computers \& Education, 62, 159-170. https://doi.org/10.1016/j.compedu.2012.10.015

Camarero, C., Rodríguez, J., \& San José, R. (2012). An exploratory study of online forums as a collaborative learning tool. Online Information Review, 36(4), 568-586. https://doi.org/10.1108/14684521211254077

Choy, D., Wong, A. F., \& Tan, S. C. (2011). Singapore student teachers' intentions and practices in integrating technology in their teaching. In G. Williams, P. Statham, N Brown, B. Cleland (Eds.), Changing Demands, Changing Directions. Proceedings ascilite Hobart 2011 (pp. 227-233). Retrieved from http://www.ascilite.org.au/conferences/hobart11/procs/Choy-concise.pdf

Compeau, D. R., \& Higgins, C. A. (1995). Computer self-efficacy: Development of a measure and initial test. MIS quarterly, 19(2), 189-211. https://doi.org/10.2307/249688

Chung, W. C. (2011). ICT integration in a "FutureSchool" in Singapore. In C. Ho \& M. Lin (Eds.), Proceedings of E-Learn: World Conference on E-Learning in Corporate, Government, Healthcare, 
and Higher Education 2011 (pp. 1118-1127). Chesapeake, VA: Association for the Advancement of Computing in Education (AACE). Retrieved from http://www.editlib.org/p/38864

Davis, F. D. (1989). Perceived usefulness, perceived ease of use, and user acceptance of information technology. MIS Quarterly, 13(3), 319-340. https://doi.org/10.2307/249008

Davis, F. D., Bagozzi, R. P., \& Warshaw, P. R. (1989). User acceptance of computer technology: A comparison of two theoretical models. Management Science, 35(8), 982-1003. https://doi.org/10.1287/mnsc.35.8.982

DeVellis, R. F. (2003). Scale development: Theory and applications (2nd ed.). Thousand Oaks, CA: Sage.

Doering, A., Hughes, J., \& Huffman, D. (2003). Preservice teachers. Journal of Research on Technology in Education, 35(3), 342-361. https://doi.org/10.1080/15391523.2003.10782390

Edmunds, R., Thorpe, M., \& Conole, G. (2012). Student attitudes towards and use of ICT in course study, work and social activity: A technology acceptance model approach. British Journal of Educational Technology, 43(1), 71-84. https://doi.org/10.1111/j.1467-8535.2010.01142.x

Fisher, R. J. (1993). Social desirability bias and the validity of indirect questioning. Journal of Consumer Research, 20(2), 303-315. https://doi.org/10.1086/209351

Fu, J. S. (2013). Complexity of ICT in education: A critical literature review and its implications. International Journal of Education \& Development using Information \& Communication Technology, 9(1), 112-125. Retrieved from http://ijedict.dec.uwi.edu/include/getdoc.php?id=5402\&article=1541\&mode=pdf

Hack, C. (2013). Using web 2.0 technology to enhance, scaffold and assess problem-based learning. Journal of Problem Based Learning in Higher Education, 1(1), 230-246. http://dx.doi.org/10.5278/ojs.jpblhe.v1i1.284

Hmelo-Silver, C. (2004). Problem-based learning: What and how do students learn? Educational Psychology Review, 16(3), 235-266. https://doi.org/10.1023/B:EDPR.0000034022.16470.f3

Hsu, C.-K., Hwang, G.-J., Chuang, C.-W., \& Chang, C.-K. (2012). Effects on learners' performance of using selected and open network resources in a problem-based learning activity. British Journal of Educational Technology, 43(4), 606-623. https://doi.org/10.1111/j.1467-8535.2011.01235.x

Hu, P. J.-H., Clark, T. H. K., \& Ma, W. W. (2003). Examining technology acceptance by school teachers: A longitudinal study. Information \& Management, 41(2), 227-241. https://doi.org/10.1016/S03787206(03)00050-8

Ioannou, A., Brown, S. W., \& Artino, A. R. (2015). Wikis and forums for collaborative problem-based activity: A systematic comparison of learners' interactions. The Internet and Higher Education, 24, 35-45. https://doi.org/10.1016/j.iheduc.2014.09.001

Kerckaert, S., Vanderlinde, R., \& van Braak, J. (2015). The role of ICT in early childhood education: Scale development and research on ICT use and influencing factors. European Early Childhood Education Research Journal, 23(2), 183-199. https://doi.org/10.1080/1350293X.2015.1016804

Kline, R. B. (2005). Principles and practice of structural equation modeling. New York, NY: Guilford.

Koç, M. (2005). Implications of learning theories for effective technology integration and pre-service teacher training: A critical literature review. Journal of Turkish Science Education, 2(1), 2-18. Retrieved from http://www.tused.org/internet/tused/archive/v2/i1/fulltext/tusedv2i1s1.pdf

Koch, S., Toker, A., \& Brulez, P. (2011). Extending the technology acceptance model with perceived community characteristics. Information Research, 16(2), 16-12. Retrieved from http://www.informationr.net/ir/16-2/paper478.html

Lew, M. N., \& Schmidt, H. (2012). Assessing student learning: Daily self-assessment at Republic Polytechnic. In G. O’Grady, E. H. J. Yew, K. P. L. Goh, \& H. G. Schmidt (Eds.), One-day, One-problem: An approach to problem-based learning (pp. 213-234). Singapore: Springer. https://doi.org/10.1007/978-981-4021-75-3_10

Lim, C. (2005). The use of online forums to support inquiry in a PBL environment: observations from a work in progress. British Journal of Educational Technology, 36(5), 919-921. https://doi.org/10.1111/j.14678535.2005.00497.x

Lin, J. M.-C., Wang, P.-Y., \& Lin, I. C. (2012). Pedagogy * technology: A two-dimensional model for teachers' ICT integration. British Journal of Educational Technology, 43(1), 97-108. https://doi.org/10.1111/j.14678535.2010.01159.x

Ma, W. W.-K., Andersson, R., \& Streith, K.-O. (2005). Examining user acceptance of computer technology: An empirical study of student teachers. Journal of Computer Assisted Learning, 21(6), 387-395. https://doi.org/10.1111/j.1365-2729.2005.00145.X

Norman, G. R., \& Schmidt, H. G. (1992). The psychological basis of problem-based learning: A review of the evidence. Academic Medicine, 67(9), 557-565. https://doi.org/10.1097/00001888-199209000-00002

O’Grady, G., Yew, E., Goh, K. P., \& Schmidt, H. (2012). One-day, one-problem: An approach to problembased learning. Singapore: Springer. https://doi.org/10.1007/978-981-4021-75-3

Pelgrum, W. J. (2001). Obstacles to the integration of ICT in education: Results from a worldwide educational assessment. Computers \& Education, 37(2), 163-178. https://doi.org/10.1016/S0360-1315(01)00045-8 
Reyes, G., \& Gabb, R. (2005). Using ICT in a problem-based learning approach. In T. van Weert \& A. Tatnall (Eds.), Information and communication technologies and real-life learning (Vol. 182, pp. 111-121). Boston, MA: Springer. https://doi.org/10.1007/0-387-25997-X_13

Sánchez, J. J. C., \& Alemán, E. C. (2011). Teachers’ opinion survey on the use of ICT tools to support attendance-based teaching. Computers \& Education, 56(3), 911-915. https://doi.org/10.1016/j.compedu.2010.11.005

Sang, G., Valcke, M., van Braak, J., \& Tondeur, J. (2010). Student teachers’ thinking processes and ICT integration: Predictors of prospective teaching behaviors with educational technology. Computers \& Education, 54(1), 103-112. https://doi.org/10.1016/j.compedu.2009.07.010

Schmidt, H. G., \& Moust, J. H. (2000). Factors affecting small-group tutorial learning: A review of research. In D. H. Evensen \& C. E. Hmelo-Silver (Eds.), Problem-based learning: A research perspective on learning interactions (pp. 19-52). Mahwah, NJ: Erlbaum.

Serhan, D. (2009). Preparing preservice teachers for computer technology integration. International Journal of Instructional Media, 36(4), 439-447. Retrieved from http://connection.ebscohost.com/c/articles/47993134/preparing-pre-service-teachers-computer-technologyintegration

Shen, C., \& Chuang, H. (2010). Exploring users' attitudes and intentions toward the interactive whiteboard technology environment. International Review on Computers and Software, 5(2), 200-208. Retrieved from http://andyrunyan.pbworks.com/w/file/fetch/55409229/Users'\%20Attitudes\%20toward\%20IWB's.pdf

Shroff, R. H., Deneen, C., \& Ng, E. M. (2011). Analysis of the technology acceptance model in examining students' behavioural intention to use an e-portfolio system. Australasian Journal of Educational Technology, 27(4), 600-618. https://doi.org/10.14742/ajet.940

Siragusa, L., \& Dixon, K. (2008). Planned behaviour: Student attitudes towards the use of ICT interactions in higher education. In Hello! Where are you in the landscape of educational technology? Proceedings ascilite Melbourne 2008 (pp. 942-953). Retrieved from http://www.ascilite.org.au/conferences/melbourne08/procs/siragusa.pdf

Smarkola, C. (2011). A mixed-methodological technology adoption study. In T. Teo (Ed.), Technology acceptance in education (pp. 9-41). Rotterdam: SensePublishers. https://doi.org/10.1007/978-94-6091-4874_ 2

Sosin, K., Blecha, B. J., Agarwal, R., Bartlett, R. L., \& Daniel, J. I. (2004). Efficiency in the use of technology in economic education: Some preliminary results. The American Economic Review, 94(2), 253-258. https://doi.org/10.1257/0002828041301623

Srivastava, T. K., Waghmare, L. S., Jagzape, A. T., Rawekar, A. T., Quazi, N. Z., \& Mishra, V. P. (2014). Role of information communication technology in higher education: Learners' perspective in rural medical schools. Journal of Clinical and Diagnostic Research: JCDR, 8(6), XC01-XC06. https://doi.org/10.7860/jcdr/2014/8371.4448

Strømsø, H. I., Grøttum, P., \& Hofgaard Lycke, K. (2004). Changes in student approaches to learning with the introduction of computer-supported problem-based learning. Medical Education, 38(4), 390-398. https://doi.org/10.1046/j.1365-2923.2004.01786.x

Tambouris, E., Panopoulou, E., Tarabanis, K., Ryberg, T., Buus, L., Peristeras, V., . . Porwol, L. (2012). Enabling problem based learning through Web 2.0 Technologies: PBL 2.0. Journal of Educational Technology \& Society, 15(4), 238-251. Retrieved from http://www.ifets.info/journals/15_4/21.pdf

Teo, T. (2009). Evaluating the intention to use technology among student teachers: A structural equation modeling approach. International Journal of Technology in Teaching and Learning, 5(2), 106-118. Retrieved from https://researchspace.auckland.ac.nz/handle/2292/10442

Teo, T., \& Van Schaik, P. (2009). Understanding technology acceptance in pre-service teachers: A structuralequation modeling approach. The Asia-Pacific Education Researcher, 18(1), 47-66. https://doi.org/10.3860/taper.v18i1.1035

Thomas, A., \& Stratton, G. (2006). What we are really doing with ICT in physical education: a national audit of equipment, use, teacher attitudes, support, and training. British Journal of Educational Technology, 37(4), 617-632. https://doi.org/10.1111/j.1467-8535.2006.00520.x

Thompson, R. L., Higgins, C. A., \& Howell, J. M. (1991). Personal computing: toward a conceptual model of utilization. MIS Quarterly, 15(1), 125-143. https://doi.org/10.2307/249443

Van De Bogart, W., \& Wichadee, S. (2015). Exploring students' intention to use LINE for academic purposes based on technology acceptance model. The International Review of Research in Open and Distributed Learning, 16(3), 65-85. https://doi.org/10.19173/irrodl.v16i3.1894

Venkatesh, V., \& Davis, F. D. (1996). A model of the antecedents of perceived ease of use: Development and test*. Decision Sciences, 27(3), 451-481. https://doi.org/10.1111/j.1540-5915.1996.tb01822.x 
Wong, K.-T., Osman, R., Choo, P. S., \& Rahmat, M. K. (2013). Understanding student teachers’ behavioural intention to use technology: technology acceptance model (TAM) validation and testing. International Journal of Instruction, 6(1), 89-104. Retrieved from http://www.e-iji.net/dosyalar/iji_2013_1_6.pdf

Wu, P. F. (2012). A mixed methods approach to technology acceptance research. Journal of the Association for Information Systems, 13(3), 172-187. Retrieved from http://aisel.aisnet.org/jais/vol13/iss3/1/

Zacharis, N. Z. (2012). Predicting college students' acceptance of podcasting as a learning tool. Interactive Technology and Smart Education, 9(3), 171-183. https://doi.org/10.1108/17415651211258281

Corresponding author: Silin Yang, valyangsilin@gmail.com

Australasian Journal of Educational Technology (c) 2017.

Please cite as: Yang, S., \& Kwok, D. (2017). A study of students' attitudes towards using ICT in a social constructivist environment. Australasian Journal of Educational Technology, 33(5), 50-62. https://doi.org/10.14742/ajet.2890 